\title{
Pentingnya Menjaga Kesehatan Ibu dan Anak di Era Pandemi Covid 19 di AKBID Sakinah Pasuruan
}

\author{
Widi Dewi Ruspitasari ${ }^{1}$, Mega Mirasaputri Cahyanti ${ }^{2^{\star}}$, dan Pipit Rosita ${ }^{3}$ \\ ${ }^{1-3}$ Institut Teknologi dan Bisnis Asia Malang \\ ${ }^{*}$ Corresponding author \\ E-mail: mega_mc@yahoo.co.id
}

\section{Article History:}

Received: 12-01-2021

Revised: 8-9-2021

Accepted: 8-9-2021
Keywords:
Abstract: Kegiatan pelatihan dilakukan di Akbid As Sakinah Pasuruan, dengan peserta mahasiswa jurusan kebidanan. Setelah membantu persalinan, problem ibu melahirkan yang sering terjadi yaitu perawatan pasca bersalin. Banyak keluhan yang dialami ibu melahirkan, salah satunya ASI kurang lancar, kulit tidak bersinar dll. Apalagi di era pandemic saat ini, dimana ibu hamil dan menyusui membutuhkan nutrisi yang cukup guna menjaga imunitas tubuh dan bayi yang baru lahir tetap bagus agar terhindar dari serangan virus. Pemenuhan kebutuhan nutrisi harian bagi ibu hamil dapat diperoleh dengan mengkonsumsi susu, yogurt, keju, jus jeruk yang diperkaya kalsium, kacang almond, ikan salmon, bayam, brokoli, dan lainnya. Namun, masih belum banyak diketahui bahwa susu yang mengundung kalsium lebih tinggi dibandingkan susu lainnya adalah susu kambing. Oleh karena itu penulis melakukan kegiatan PKM dengan Tema 'Meningkatkan Kesehatan Ibu dan Anak di Masa Pandemi Covid 19", melalui konsumsi susu kambing dan olahan lainnya. Dalam kegiatan PKM ini penulis menjelaskan tentang manfaat susu kambing untuk ibu hamil dan menyusui. Terdapat lebih banyak oligosakarida dalam kandungan susu kambing yang dapat menjaga saluran pencernaan sehingga baik untuk imun tubuh, dimana hal tersebut dapat membantu meminimalisir virus masuk ke tubuh. Susu kambing yang memiliki kandungan terbaik dihasilkan dari jenis PE etawa. Walaupun belum banyak masyarakat yang mengenal susu kambing, namun masih ada masyarakat yang lebih memilih susu kambing untuk menyembuhkan penyakit tertentu, seperti alergi. Dapat disimpulkan bahwa kegunaan dari susu kambing diantaranya: 1. Membantu penyerapan nutrisi makanan, 2. Menyehatkan saluran pencernaan, 3. Meningkatkan sistem imun, 4. Mengobati diabetes, 5. Mengobati gangguan pernapasan, 6 . Mengobati penderita psoriasis, 7. Mencegah penyakit saraf, dan 8. Membantu meningkatkan kecerdasan.

Susu Kambing, KIA 


\section{Pendahuluan}

Mewabahnya virus Corona disemua negara memberikan dampak tersendiri terhadap aktivitas manusia (Burhanuddin \& Abdi, 2020; Mansyur, 2020; A. K. Sari \& Febrianti, 2020). Dampak yang dirasakan memaksa manusia untuk merubah cara pandang mengenai Kesehatan yang harus selalu menjadi prioritas. Memasuki era new normal, terdapat penyesuain yang harus dilakukan oleh manusia dalam melakukan aktivitasnya sehari-hari seperti selalu melakukan protocol Kesehatan dengan 3M; mencuci tangan, memakai masker, menjaga jarak.

Berdasarkan hasil survey, lebih dari $73 \%$ memiliki perasaan takut akan tertular oleh virus corona (A. K. Sari \& Febrianti, 2020), Ketika harus melakukan aktivitas seperti semula. Kekuatiran ini juga dialami oleh ibu hamil dan menyusui. Sehingga harus segera dicarikan solusinya untuk para ibu hamil dan menyusui yang tetap memberikan dampak aman pada kedua belah pihak. Salah satu solusi yang dapat diberikan adalah dengan memberikan asupan gizi dan vitamin yang cukup untuk menunjang kesehatan ibu dan anak. Salah satu asupan yang bagus adalah dengan mengkonsumsi susu kambing secara rutin. Kesehatan ibu dan anak menjadi suatu perhatian khusus, karena ibu hamil dan menyusui harus mendapatkan asupan nutrisi yang sesuai dengan kebutuhan (Dewi, 2018; Sabil, 2015; D. A. Sari \& Hadiyanto, 2013).

Dalam kegiatan PKM ini penulis menjelaskan pentingnya konsumsi susu kambing untuk ibu dan anak serta metode pengolahan susu kambing yang benar demi menjaga kandungan nutrisi didalamnya utuh agar lebih maksimal memberikan dampak positif bagi kesehatan. Dalam dunia medis, pemberian multivitamin saja tidak cukup tanpa diimbangi asupan nutrisi yang dikonsumsi ibu hamil dan menyusui (Dewi, 2018).

Permasalahan yang dialami Akbid Sakinah Pasuruan, salah satunya yaitu dalam mengkonsumsi susu kambing, akan muncul bau prengus saat dikonsumsi. Bau prengus ini memang ciri khas dari susu kambing, tetapi hal ini dapat diminimalisir dengan menambahkan rasa dalam susu kambing. Selain itu juga, pengolahan dari susu kambing tidak hanya sebatas untuk dikonsumsi, melainkan dapat juga dijadikan minuman kefir yang mengandung unsur probiotik serta masker wajah untuk menunjang kecantikan (Sabil, 2015; Saleh, 2004).

Penulis melakukan diskusi melalui aplikasi Whatsapp dengan Akbid Sakinah Pasuruan sebelum menentukan materi pelatihan. Berdasarkan hasil diskusi dapat ditentukan permasalahan yang harus ditangani untuk Meningkatkan Kesehatan lbu dan Anak di Masa Pandemi Covid 19 yaitu: a. Memberikan edukasi kepada para mahasiswa Akbid Sakinah, nutrisi alami yang baik dikonsumsi ibu hamil dan menyusui, b. Memberikan edukasi cara mengolah susu kambing untuk mengurangi bau prengus. 


\section{Metode}

Kegiatan pengabdian ini melalui beberapa tahapan proses pasteurisasi (Sabil, 2015; D. A. Sari \& Hadiyanto, 2013) yang dapat dilihat secara rinci pada Gambar 1 yaitu (1) Memasukan susu segar pada panci yang berbahan dasar stainless steel kedalam panci yang ukurannya lebih besar dan sudah diisi oleh air (seperti proses tim), kemudian lakukan proses pasteurisasi secara manual dengan cara memanaskan susu menggunakan api sangat kecil sampai mencapai suhu 85 derajat celcius selama 5 menit (Sabil, 2015); (2) Setelah itu angkat panci susu dan segera kagetkan dengan cara mencelupkan pada air es dingin sampai suhu susu mencapai 22 derajat celcius; (3) Campur susu dengan rasa yang diinginkan; (4) Simpan dalam freezer agar susu awet sampai dengan 3 bulan atau kulkas bawah dengan daya tahan sampai 3 minggu (D. A. Sari \& Hadiyanto, 2013).

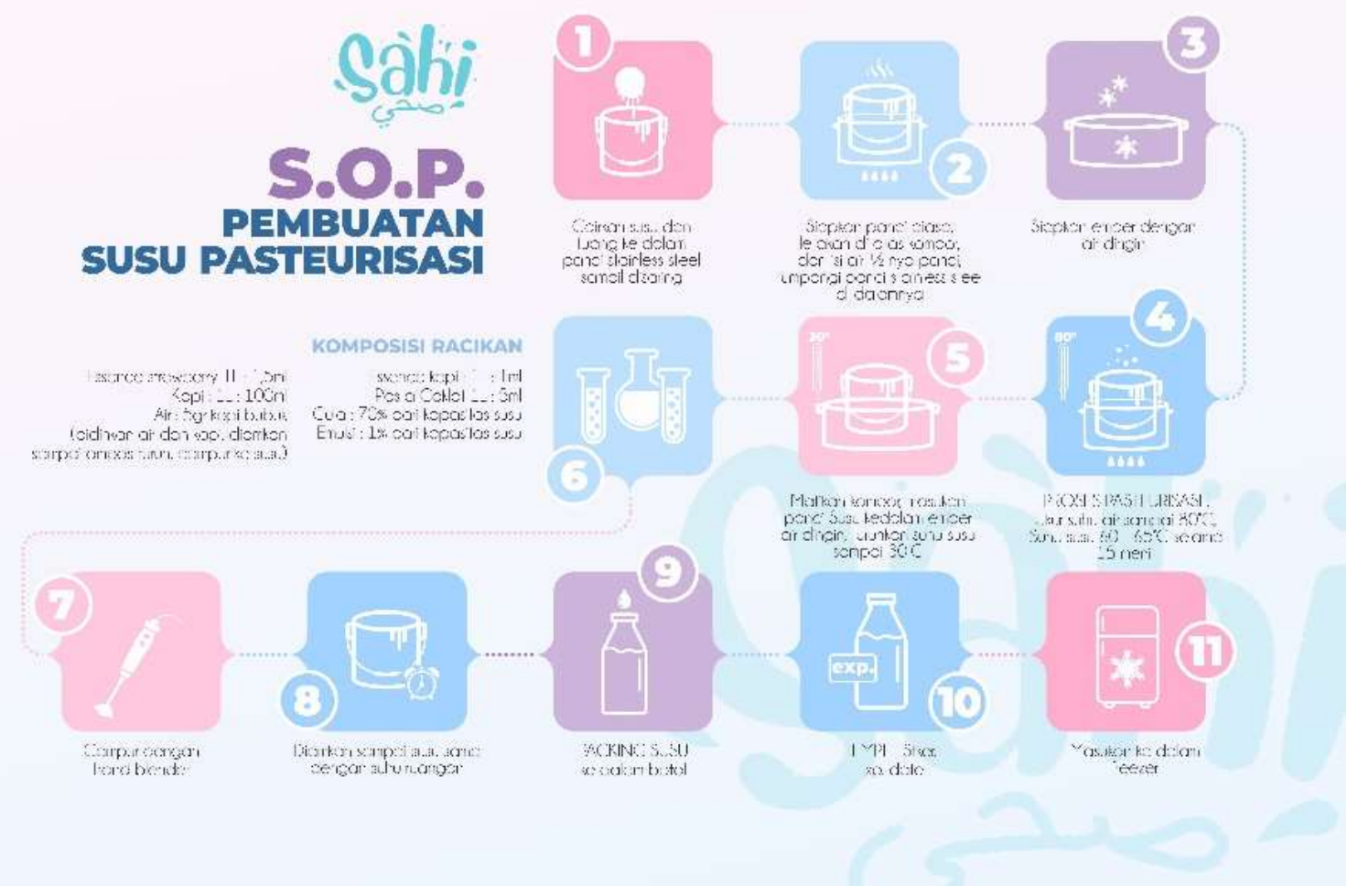

Gambar 1. SOP Pasteurisasi Susu Kambing

\section{Hasil}

Pelatihan yang dilakukan melalui online memberikan pengetahuan terhadap peserta terhadap tiga (3) hal, diantaranya, pertama, manfaat susu kambing diantaranya adalah membantu penyerapan nutrisi makanan, menyehatkan saluran pencernaan, meningkatkan sistem imun, mengobati diabetes, mengobati gangguan pernapasan, mengobati penderita psoriasis, mencegah penyakit saraf, dan membantu meningkatkan kecerdasan serta engobati anemia (Murtidjo, 1993). Kedua, kandungan dan karakteristik susu kambing terdiri dari yaitu susu kambing memiliki warna lebih 
jernih, globula lemak susu lebih kecil dengan diameter 0,73-8,58 $\mu \mathrm{m}$, mengandung mineral kalsium, fosfor, vitamin $A, E$ dan $B$ kompleks yang tinggi, dapat diminum oleh orang-orang yang alergi minum susu sapi dan untuk orang-orang yang mengalami berbagai gangguan pencernaan (lactose intolerance), dari segi produktivitas, produksi susu kambing lebih cepat diperoleh karena kambing telah dapat berproduksi pada umur 1,5 tahun, sedangkan sapi baru dapat berproduksi pada umur 3 - 4 tahun, tergantung ras (Saleh, 2004). Ketiga, proses pasteurisasi susu kambing dan penyimpanannya.

\section{Diskusi}

Hasil pengabdian masyarakat pada AKBID Sakinah menghasilkan adanya transfer knowledge dari kedua belah pihak. Dimana selain materi yang disampaikan, tercipta diskusi lebih lanjut dari dua arah yang mendapati sebuah kesepakatan bahwa perlu diadakannya penyuluhan terhadap ibu dan anak untuk memulai kebiasaan baru dalam mengkonsumsi jenis susu kambing sebagai supplemen Kesehatan khususnya di era pandemic Covid 19 saat ini. Diskusi diatas didukung pula oleh hasil penelitian yang dilkukan oleh (Dewi, 2018) dengan hasil penelitian yang diperoleh adalah untuk sampel susu kambing, Kadar protein rata - ratanya adalah 5,69 \%, untuk kadar kalsium dari sampel susu kambing PE adalah : 30,76\% dan pemeriksaan jumlah angka lempeng total diperoleh 0 koloni / $\mathrm{ml}$. Dari hasil penelitian menunjukkan bahwa susu kambing peranakan etawah (PE) layak dikonsumsi oleh masyarakat, sebagai sumber gizi yang sangat diperlukan oleh tubuh khususnya bagi Wanita hamil dan anak-anak.

Pelatihan yang dilakukan melalui online memberikan pengetahuan terhadap peserta terhadap tiga (3) hal, diantaranya, pertama, manfaat susu kambing diantaranya adalah membantu penyerapan nutrisi makanan, menyehatkan saluran pencernaan, meningkatkan sistem imun, mengobati diabetes, mengobati gangguan pernapasan, mengobati penderita psoriasis, mencegah penyakit saraf, dan membantu meningkatkan kecerdasan serta engobati anemia (Murtidjo, 1993). Kedua, kandungan dan karakteristik susu kambing terdiri dari yaitu susu kambing memiliki warna lebih jernih, globula lemak susu lebih kecil dengan diameter 0,73-8,58 $\mu \mathrm{m}$, mengandung mineral kalsium, fosfor, vitamin A, E dan B kompleks yang tinggi, dapat diminum oleh orang-orang yang alergi minum susu sapi dan untuk orang-orang yang mengalami berbagai gangguan pencernaan (lactose intolerance), dari segi produktivitas, produksi susu kambing lebih cepat diperoleh karena kambing telah dapat berproduksi pada umur 1,5 tahun, sedangkan sapi baru dapat berproduksi pada umur 3 - 4 tahun, tergantung ras (Saleh, 2004). Ketiga, proses pasteurisasi susu kambing dan penyimpanannya. 
Mewabahnya virus Corona disemua negara memberikan dampak tersendiri terhadap aktivitas manusia (Burhanuddin \& Abdi, 2020; Mansyur, 2020; A. K. Sari \& Febrianti, 2020). Dampak yang dirasakan memaksa manusia untuk merubah cara pandang mengenai Kesehatan yang harus selalu menjadi prioritas. Memasuki era new normal, terdapat penyesuain yang harus dilakukan oleh manusia dalam melakukan aktivitasnya sehari-hari seperti selalu melakukan protocol Kesehatan dengan 3M; mencuci tangan, memakai masker, menjaga jarak.

Berdasarkan hasil survey, lebih dari 73\% memiliki perasaan takut akan tertular oleh virus corona (A. K. Sari \& Febrianti, 2020), Ketika harus melakukan aktivitas seperti semula. Kekuatiran ini juga dialami oleh ibu hamil dan menyusui. Sehingga harus segera dicarikan solusinya untuk para ibu hamil dan menyusui yang tetap memberikan dampak aman pada kedua belah pihak. Salah satu solusi yang dapat diberikan adalah dengan memberikan asupan gizi dan vitamin yang cukup untuk menunjang kesehatan ibu dan anak. Salah satu asupan yang bagus adalah dengan mengkonsumsi susu kambing secara rutin. Kesehatan ibu dan anak menjadi suatu perhatian khusus, karena ibu hamil dan menyusui harus mendapatkan asupan nutrisi yang sesuai dengan kebutuhan (Dewi, 2018; Sabil, 2015; D. A. Sari \& Hadiyanto, 2013).

Dalam kegiatan PKM ini penulis menjelaskan pentingnya konsumsi susu kambing untuk ibu dan anak serta metode pengolahan susu kambing yang benar demi menjaga kandungan nutrisi didalamnya utuh agar lebih maksimal memberikan dampak positif bagi kesehatan. Dalam dunia medis, pemberian multivitamin saja tidak cukup tanpa diimbangi asupan nutrisi yang dikonsumsi ibu hamil dan menyusui (Dewi, 2018).

Permasalahan yang dialami Akbid Sakinah Pasuruan, salah satunya yaitu dalam mengkonsumsi susu kambing, akan muncul bau prengus saat dikonsumsi. Bau prengus ini memang ciri khas dari susu kambing, tetapi hal ini dapat diminimalisir dengan menambahkan rasa dalam susu kambing. Selain itu juga, pengolahan dari susu kambing tidak hanya sebatas untuk dikonsumsi, melainkan dapat juga dijadikan minuman kefir yang mengandung unsur probiotik serta masker wajah untuk menunjang kecantikan (Sabil, 2015; Saleh, 2004).

\section{Kesimpulan}

Pelatihan Bersama para mahasiswa yang dapat disebut sebagai calon bidan di AKBID Sakinah, Pasuruan merupakan salah satu cara untuk mulai memperkenalkan susu kambing terhadap masyarakat khususnya ibu dan anak. Bahwa susu kambing dapat diolah memiliki kandungan gizi yang lebih baik dibandingkan susu lainnya. Serta melalui proses pengolahan yang benar, susu kambing tidak akan mengeluarkan bau prengus. 


\section{Pengakuan/Acknowledgements}

Ucapan terima kasih diberikan kepada AKBID Sakinah serta lembaga LP2M dari Institut Asia yang telah mendukung terlaksananya program transfer knowledge ini. Sehingga masing-masing institusi dapat menjalin Kerjasama jangka panjang dalam hal pengetahuan dan hasil penelitian yang terkait.

\section{Daftar Referensi}

Burhanuddin, C. I., \& Abdi, M. N. (2020). Krisis Ekonomi Global Dari Dampak Penyebaran Virus Corona (COVID-19). AkMen JURNAL ILMIAH, 17(1), 90-98. https://doi.org/10.37476/akmen.v17i1.866

Dewi, R. (2018). Analisis Kandungan Zat Gizi dan Total Uji Cemaran Susu Kambing Peranakan Etawah yang Dikonsumsi oleh Ibu Hamil dan Anak-Anak. Media Farmasi, 14(1), 71-76. https://doi.org/10.32382/mf.v14i1.73

Mansyur, A. R. (2020). Dampak COVID-19 Terhadap Dinamika Pembelajaran Di Indonesia. Education and Learning Journal, 1(2), 113-123. https://doi.org/10.33096/eljour.v1i2.55

Murtidjo, B. A. (1993). Memelihara Domba (1st ed.). Kanisius. https://opac.perpusnas.go.id/DetailOpac.aspx?id=517196

Sabil, S. (2015). Pasteurisasi High Temperature Short Time (HTST) Susu terhadap Listeria Monocytogenes Pada Penyimpanan Refrigerator. Universitas Hasanudin.

Saleh, E. (2004). Dasar Pengolahan Susu dan Hasil Ikutan Ternak. Program Studi Produksi Ternak Fakultas Pertanian Universitas Sumatera Utara.

Sari, A. K., \& Febrianti, T. (2020). Gambaran Epidemiologi dan Stigma Sosial Terkait Pandemi COVID-19 Di Kota Tangerang Selatan Tahun 2020. Collaborative Medical Journal (CMJ), 3(3), 104-109. https://doi.org/10.36341/cmj.v3i3.1506

Sari, D. A., \& Hadiyanto, H. (2013). Teknologi dan Metode Penyimpanan Makanan Sebagai Upaya Memperpanjang Shelf Life. Jurnal Aplikasi Teknologi Pangan, 2(2), 52-59. 